\title{
Peran Sistem Informasi dan Teknologi Informasi terhadap Proses Pembelajaran di Masa Pandemi Covid-19
}

\author{
Saifan Shodiq \\ Universitas Islam Negeri Jember \\ Jl. Mataram No.1, Karang Mulwo, Mangli, Kec. Kaliwates, Kabupaten Jember, Jawa Timur 68136 \\ E-mail: Saifan48shodiq@gmail.com
}

\begin{abstract}
Abstrak
Penyebaran wabah virus Covid-19 diseluruh dunia melumpuhkan segala lini kehidupan, tak terkecuali pada dunia pendidikan. Sehingga, lembaga pendidikan harus mencari solusi agar kegiatan belajar mengajar masih bisa dilangsungkan. Tujuan penulisan artikel ini adalah untuk memaparkan peran sistem informasi manajemen (SIM) pendidikan dan teknologi informasi terhadap proses pembelajaran di masa pandemic Covid-19. Metode penulisan artikel ini adalah studi literasi. Hasil dari studi literasi menunjukkan bahwa sistem informasi manajemen dan teknologi informasi sangat berperan pada pembelajaran jarak jauh. Teknologi informasi berperan sebagai wadah atau sebagai sarana pembelajaran, sedangkan sistem informasi berperan sebagai otak dalam pembelajaran jarak jauh. Namun, sebelum melaksanakan pembelajaran jarak jauh, lembaga pendidikan harus mempersiapkan beberapa hal seperti sarana prasarana pembelajaran jarak jauh dan litersi TIK pendidik dan peserta didik. Hal-hal tersebut menjadi penentu dalam mencapai keberhasilan pembelajaran jarak jauh.
\end{abstract}

Kata Kunci: Sistem Informasi Manajemen, Teknologi Informasi, Pembelajaran Jarak Jauh

\section{Abstract}

The spread of the Covid-19 virus outbreak throughout the world has paralyzed all lines of life, including in the world of education. So, educational institutions must find solutions so that teaching and learning activities can still be carried out. The purpose of writing this article is to describe the role of management information systems (SIM) for education and information technology in the learning process during the Covid-19 pandemic. The method of writing this article is literacy study. The results of the literacy study indicate that management information systems and information technology play a major role in distance learning. Information technology acts as a container or as a means of learning, while information systems act as the brain in distance learning. However, before implementing distance learning, educational institutions must prepare several things such as distance learning infrastructure and ICT literacy for educators and students. These things are decisive in achieving distance learning success.

Keywords: Management Information Systems, Information Technology, Distance Learning

\section{Pendahuluan}

Seiring dengan arus globalisasi yang semakin mendunia, kini kebutuhan informasi sangatlah penting bagi semua lembaga, tak terkecuali lembaga pendidikan. Informasi merupakan kebutuhan primer bagi manusia. Tanpa informasi akan sulit bagi seorang manajer untuk mengambil keputusan, baik dari informasi iternal yang disiapkan oleh perusahaan itu sendiri atau dari informasi eksternal yang dapat diperoleh dari alat-alat komunikasi modern lainnya. Pengelolaan sistem informasi manajemen yang tepat merupakan salah satu hal penting dalam mempertahankan bahkan mengembangkan sebuah lembaga pendidikan [1]. Oleh karena itu, seorang pemimpin ataupun manajer lembaga pendidikan haruslah orang yang tidak hanya memiliki jiwa kepemimpinan, tetapi juga harus memilik kemampuan manajerial yang sangat mumpuni.

Teknologi informasi dan sistem pendidikan juga harus berjalan seimbang dengan peningkatan sumber daya manusia (SDM), karena, sumber daya manusia merupakan komponen utama yang dibutuhkan untuk menghasilkan sistem informasi manajemen pendidikan yang berkualitas dan efisien. Dalam dunia pendidikan, aktivitas pendidikan tidak bisa dipisahkan dengan sistem informasi manajemen (SIM) pendidikan, karena keduanya saling berkaitan dan membutuhkan satu sama lain. Hubungan dari kedua aspek tersebut dapat digambarkan bahwa pendidikan dinilai sebagai penggerak Sistem informasi manajemen, sedangkan sistem informasi manajemen menjadi penentu kinerja pendidikan [2]. Hal itu berarti dalam menjalankan pendidikan, peran sistem informasi manajemen tidak bisa dihilangkan.

Pada umumnya, sistem informasi manajemen merupakan suatu sistem yang diciptakan sebagai alat pengolah data, yang berfungsi untuk menunjang tugas-tugas manajerial seperti evaluasi dan pengambilan keputusan. Kemajuan teknologi informasi dan komunikasi (TIK) berperan penting dalam perkembangan sistem informasi manajemen. Pada awalnya, semua hal dilakukan secara manual, namun pada saat ini, semua hal dapat ditunjang oleh perangkat komputer. Sehingga, pemrosesan data terkait dengan sistem informasi manajemen bisa lebih cepat dan 
akurat. Hal itu menunjukkan bahwa teknologi informasi dan komunikasi (TIK) dapat meningkatkan kinerja sistem informasi manajemen.

Namun, mewabahnya virus Covid-19 diseluruh dunia, sempat menjadi faktor penghambat dalam semua lini kehidupan manusia, tak terkecuali didalam pendidikan itu sendiri. Lembaga pendidikan terpaksa harus melaksanakan pembelajaran menggunakan E-Learning (pembelajaran berbasis elektronik). Disinilah peran teknologi tidak lagi bisa disepelehkan. Dampaknya adalah, lembaga pendidikan berlomba-lomba untuk mengembangkan sarana pembelajaran berbasis internet dan elektronik demi keberlangsungan proses belajar mengajar.

Berdasarkan latar belakang diatas dapat disimpulkan bahwa, pada artikel ini, penulis akan membahas mengenai peran sistem informasi dan teknologi informasi terhadap proses pembelajaran di masa pandemi Covid-19. Tujuan penulisan artikel ini adalah untuk memberikan informasi terkait fungsi sistem informasi dan teknologi informasi dalam proses belajar mengajar yang berbasis elektronik di masa pandemi Covid-19. Sehingga, penulis berharap bahwa di waktu yang akan datang, pembahasan mengenai sistem informasi dan teknologi informasi tidak hanya sebatas pada perannya saja, tetapi lebih jauh pada cara-cara yang bisa digunakan untuk memaksimalkan kinerja keduanya.

\section{Pembahasan}

Sistem informasi manajemen pendidikan yaitu kumpulan komponen yang sama-sama bergerak untuk menyimpan, mengolah, dan membagikan informasi pendidikan, yang pada nantinya digunakan sebagai dasar pengambilan keputusan dalam sebuah lembaga pendidikan. Tujuan sistem informasi manajemen pendidikan antara lain; Menyediakan informasi yang dapat digunakan untuk membuat perencanaan, pengendalian, proses pengevaluasian, dan perbaikan suatu program; Memberikan informasi yang diperlukan untuk kepentingan data siswa, nilai siswa, dan tujuan yang ingin dicapai oleh manajemen sekolah; Sebagai bahan pertimbangan dalam pengambilan keputusan organsasi [3]. Sehingga dapat disimpulkan bahwa tujuan sistem informasi manajemen adalah menyediakan data yang valid untuk kemudian dijadikan sebagai acuan dalam menentukan suatu kebijakan.

Dimasa pandemi ini, peran sistem informasi manajemen pendidikan sangatlah signifikan yaitu; SIM dapat meningkatkan aksebilitas data yang tersedia secara tepat waktu dan akurat bagi para pemakai, tanpa mengharuskan adanya perantara dari sistem informasi yang ada; SIM membantu mengembangkan proses perencanaan yang lebih efektif dan efisien; SIM dapat mengantisipasi serta memahami konsekuensi ekonomis baik dari sistem informasi dan teknologi baru yang berkembang; Sekolah dapat menggunakan sistem informasi untuk dapat mengolah data transaksi, mengurangi biaya dan memberikan pendapatan sebagai suatu produk pelayanan; SIM dapat menganalisis suatu kebutuhan-kebutuhan informasi yang diperlukan; SIM sebagai pengendalian manajemen adalah untuk mengukur pekerjaan, memutuskan tindakan pengendalian, merumuskan aturan tentang keputusan baru untuk diterapkan pada personalia operasional, serta mengalokasikan sumber daya yang telah tersedia [3]. Hal itu berarti peran sistem informasi manajemen pendidikan di masa pandemic ini sangatlah sentral.

Peran SIM pendidikan di masa pandemi yang sangat terlihat jelas adalah pada manajemen kurikulum/ pembelajaran. Perubahan dari pertemuan tatap muka didalam kelas, kepada pertemuan menggunakan media elektronik tidak bisa dianggap sepeleh. Jika salah mengambil langkah, bisa-bisa pembelajaran tidak bisa berjalan dengan baik. Salah satu sarana SIM pendidikan di masa pandemi ini adalah E-Learning. Didalam E-Learning, terdapat interaksi antara guru dan murid, seperti pembelajaran pada umumnya. Namun, yang sedikit berbeda adalah, semua hal yang berkaitan dengan pembelajaran harus diunggah ke sistem Elearning, seperti daftar hadir, tugas harian, materi pembelajaran, dan penilaian harian. Sehingga, lembaga pendidikan membutuhkan SIM pendidikan yang cukup tangguh untuk meng-cover semua kebutuhan pendidik dan peserta didik saat proses belajar mengajar.

Pembahasan selanjutnya yaitu mengenai peran teknologi informasi dan komunikasi dalam pembelajaran di masa pandemi. Teknologi informasi dan komunikasi merupakan peralatan elektronika yang terdiri dari perangkat keras dan perangkat lunak serta segala kegiatan yang terkait dengan pemrosesan, manipulasi, pengolahan, dan transfer atau pemindahan informasi antar media [4]. Perangkat keras adalah semua alat atau perangkat yang secara fisik dapat kita sentuh seperti, komputer, ponsel, radio, televisi, dll. Sedangkan perangkat lunak adalah sebuah sistem ataupun aplikasi yang terdapat dalam perangkat keras.

Dalam perjalanannya, teknologi informasi dan komunikasi mengalami perkembangan yang sangat pesat. Industri perangkat keras dan perangkat lunak berlombalomba untuk memproduksi teknologi yang paling mutahir agar dapat mempermudah pekerjaan manusia. Sehingga, di era globalisasi ini, tidak heran jika banyak pekerjaan manusia yang telah digantikan dengan teknologi. Peran TIK dalam pembelajaran ditengah pandemi ini juga tidak kalah signifikan. Tidak diperbolehkannya kelas tatap muka menyebabkan pemerintah serta lembaga pendidikan memutar otak. Pemanfaatan TIK adalah jalan alternatif yang bisa ditempuh. Namun, terdapat 5 kriteria penting yang harus dipenuhi jika lembaga pendidikan ingin menggunakan TIK untuk mendukung pembelajaran selama masa pandemic [5] yaitu: Penerapan teknologi informasi dan komunikasi harus menyediakan kemudahan dalam akses sumber daya pembelajaran pada sumber belajar; Penerapan teknologi informasi dan komunikasi harus menghadirkan kesamaan kondisi pembelajaran virtual dengan lingkungan belajar yang tradisional (kelas tatap muka); Penerapan teknologi informasi dan komunikasi harus menghadirkan sistem pembelajaran yang efektif dengan memanfaatkan dan menggunakan learning mangement system (LMS); penerapan teknologi informasi dan komunikasi harus memfasilitasi semua pengguna tanpa terbatas pada pengalaman menggunakan teknologi tersebut; penerapan teknologi informasi dan komunikasi harus mampu menjadi media interaksi antara pengajar dan pembelajar, khususnya 
ketika pembelajar mengalami kesulitan dan ingin bertanya kepada pengajarnya.

Pada dasarnya peran TIK dalam pembelajaran dimasa pandemic adalah menyediakan wadah untuk melakukan pembelajaran jarak jauh, sehingga tidak ada halangan bagi pendidik dan peserta didik untuk melakukan pembelajaran. Jika membahas mengenai teknologi informasi dan komunikasi dalam dunia pendidikan, seringkali kita menemukan beberapa permasalahan salah satunya adalah mengenai literasi TIK. Literasi teknologi informasi dan komunikasi merupakan kemampuan menggunakan TIK untuk menemukan, menilai, menggunakan, membuat dan mengkomunikasikan informasi, dalam pelaksanaannya kemampuan-kemampuan tersebut membutuhkan kemampuan kognitif dan keterampilan teknik [6]. Dengan kata lain, literasi TIK merupakan kemampuan untuk mengoperasikan baik perangkat keras dan perangkat lunak.

Literasi teknologi informasi dan komunikasi dalam pembelajaran jarak jauh di masa pandemi secara tidak langsung menjadi faktor penentu. Kemampuan mengoperasikan teknologi informasi dan komunikasi baik oleh pendidik maupun peserta didik bisa menentukan berhasil atau tidaknya sebuah pembelajaran. Hal ini sangat berdampak bagi pendidik maupun peserta didik. Dampaknya bagi peserta didik adalah peserta didik akan lebih mudah dalam mengakses materi pembelajaran, mengunggah tugas harian, atau bahkan sekdar mengisi kehadiran. Sedangkan dampak literasi TIK bagi pendidik adalah mempermudah dalam menyampaikan materi pembelajaran, mempermudah dalam mengawasi dan mengontrol peserta didik saat pembelajaran berlangsung, dan mempermudah untuk menerima hasil tugas harian peserta didik.

Pada konteks efektifitas pembelajaran jarak jauh, pengetahuan tentang perangkat teknologi dan kemampuan dasar dalam pengoperasian teknologi merupakan literasi teknologi paling dasar yang mendorong dalam menciptakan lingkungan pembelajaran jarak jauh yang lebih efektif. Literasi teknologi dasar mengenai cara penggunaan sistem teknologi perlu dilatihkan dan ditingkatkan agar pembelajaran jarak jauh bisa lebih efektif [7]. Dengan kata lain, sebelum melakukan pembelajaran jauh, lembaga pendidikan harus memastikan bahwa baik pendidik maupun peserta didik memiliki kemampuan dasar menggunakan TIK. Jika kemampuan yang diinginkan belum seluruhnya tercapai, maka lembaga pendidikan dapat melakukan pelatihan. Pelatihan bisa dilakukan dengan 2 langkah. Langkah pertama adalah pengenalan perangkat keras yang terintegrasi dengan sistem pembelajaran jarak jauh. Langkah kedua yaitu pelatihan pembelajaran jarak jauh dengan metode praktik langsung, artinya pendidik ataupun peserta didik melaksanakan pembelajaran dengan bimbingan oleh teknisi ahli. Pelatihan tersebut tidak bisa hanya dilakukan sekali dua kali, namun harus berkali-kali. Sehingga, pemahaman mengenai perangkat dan aplikasi yang digunakan untuk pembelajaran jarak jauh bisa maksimal.

\section{Kesimpulan dan Saran}

Sistem informasi manajemen pendidikan yaitu kumpulan komponen yang sama-sama bergerak untuk menyimpan, mengolah, dan membagikan informasi pendidikan, yang pada nantinya digunakan sebagai dasar pengambilan keputusan dalam sebuah lembaga pendidikan. Sedangkan, teknologi informasi dan komunikasi merupakan kumpulan instrumen yang meliputi perangkat keras dan perangkat lunak yang digunakan dalam kegiatan yang terkait dengan pemrosesan, manipulasi, pengolahan, dan transfer atau pemindahan informasi antar media. Kedua hal tersebut saling berkaitan dan tidak dapat dipisahkan satu sama lain dalam dunia pendidikan. Pada masa pandemic ini, peran keduanya sangat signifikan. Teknologi informasi dan komunikasi berperan sebagai wadah ataupun sarana dalam pembelajaran jarak jauh, sedangkan sistem informasi manajemen berperan sebagai inti untuk menyampaikan informasi terkait pembelajaran. Dalam melaksanakan pembelajaran jarak jauh, literasi teknologi informasi dan komunikasi menjadi penentu karena ini terkait dengan kemampuan pendidik dan peserta didik untuk mengoperasikan baik perangkat keras maupun perangkat lunak TIK. Oleh karena itu, sebelum melakukan pembelajaran jarak jauh, lembaga pendidikan harus memperhatikan beberapa hal yaitu, kesiapan sarana prasarana, kondisi dan letak geografis pendidik dan peserta dídik, serta literasi teknologi informasi dan komunikasi.

Saran penulis untuk peneliti selanjutnya adalah peneliti selanjutnya dapat menggunakan lebih banyak referensi dalam penyusunan karya ilmiah dengan tema yang sama. Sedangkan, saran untuk lembaga pendidikan adalah lembaga pendidikan harus memenuhi syarat-syarat yang dibutuhkan untuk melakasanakan pembelajaran jarak jauh. Sehingga, pembelajaran jarak jauh dapat dilaksanakan dengan baik.

\section{Daftar Pustaka}

[1] Helmawati, Sistem Informasi Manajemen, Bandung: PT. Remaja Rosdakaya, 2015, h. 1.

[2] Eti Rochaety, dkk, Sistem Informasi Manajemen Pendidikan, Jakarta:PT. Bumi Aksara, 2005.

[3] Nilhuda, L, Peranan Sistem Informasi Manajemen dalam Meningkatkan Kualitas Pendidikan, Jurnal, Padang:Universitas negeri Padang. 2016.

[4] Rusman dkk, Pembelajaran Berbasis Teknologi Informasi dan Komunikasi, (Jakarta: Grafindo persada, 2012), hal. 88

[5] Huang, R. H., Liu, D. J., Tlili, A., Yang, J. F., \& Wang, H. H. Handbook on facilitating flexible learning during educational disruption: The Chinese experience in maintaining undisrupted learning in COVID-19 Outbreak. Smart Learning Institute of Beijing Normal University: UNESCO. 2020: 1-54

[6] Yazon, A., D, et al. Digital Literacy, Digital Competence and Research Productivity of Educator. Universal Journal of Education Research. 2019; 7(8): 1734-1743.

[7] Keskin, N, O., Ozata, F, Z., Banar, K. Examining Digital Literacy Competences and Learning Habits of Open and Distance Learners. Contemporary Educational Technology. 2015; 6(1): 74-90 